\title{
INDIVIDUAL OR COMMUNITY - WE ARE FAILING ALTOGETHER: A SHORT COMMUNICATION
}

\author{
Suman Mukherjee* \\ Department of Periodontology and Oral Implantology, Arogya Bardini Polyclinic, Puruliya, West Bengal, India. \\ Email: smjee234@gmail.com
}

Received: 10 February 2021, Revised and Accepted: 23 April 2021

\section{ABSTRACT}

This author critically and rationally appraises the present state of affairs and presents a contemporary perspective.

Keywords: Community, Continent, Individual, Life, Religion.

(C) 2021 The Authors. Published by Innovare Academic Sciences Pvt Ltd. This is an open access article under the CC BY license (http://creativecommons.org/ licenses/by/4.0/) DOI: http://dx.doi.org/10.22159/ijss.2021v9i3.41059. Journal homepage: https://innovareacademics.in/journals/index.php/ijss

\section{MANUSCRIPT}

The biggest question since the past decades were related to psychology. Who are we? We are our purpose? Is there life after death?

Today, curiosity [1] and interest are back to social psychology. The paradigm is shifted towards criminology, the study of human minds, social behavior, and space.

In essence, the question, for now, is: Where we weigh up to our ancestors? Are we progressing? With all the latest inventions and exegesis, interpretation of inscriptions, did we stand out or behind?

Present-day, individuals are more distant apart from one's mind (thoughts/ thinking) and heart (feelings) than two continents. We are like confused escapists who are running away from anything and everything, utmost ourselves. As a community or society, we are like different species of wild animals living together with no basic interaction with one another. We leap at the infinitesimal possibility of gas lighting and scrimmage, yet we seldom stand for/together for a better cause. Coming forward as a community for a cause is a myth now. It's the individual responsibility; as heroism as we say.

Nowadays, everything is in crisis. Self or other. Nearly all of us suffer from anxiety, depression, complexes, or frustrations within. As we step outside ourselves and look at the world, hate, resentment, religion, politics, population, pollution, unemployment, crime, and climate change. It's as if there's a never-ending list of worries.

In these circumstances, the fair question to ask is: Are we fulfilling anything at all? How is human life anything, as it is not better than animal life? Isn't our existence causing more pain and suffering to ourselves, the society, the community, and so on?
So, the question we need to ask is: Are we failing? Individually and as a community.

In a classic study of bacterial culture, Lane Claypon [2] has described four stages of bacterial culture. The single bacterium multiplies, grows in number, fights each other for existence and sustenance, and declines, ultimately perishing. Research says, all of us plants and animals follow these four stages: Growth, multiply, stationary, and decline. Looking at our human generations, you find human reproductive capacity is declining, food shortage and stress (life, career, space) are resulting in war, drought, and loss of world stability. In short, we are heading toward the decline phase due to population outbursts in recent decades.

Carl Sagan once quoted "some 5 billion years from now, after it's burned to a crisp, or even swallowed by the Sun, there will be other worlds and stars and galaxies coming into being - and they will know nothing of a place once called Earth." Maybe, it's time we set aside our differences and make the world a better place following our ancestral footsteps because sooner or later we all will perish along with all our theories, research, and credibility.

\section{AUTHOR'S CONTRIBUTIONS}

Dr. Suman Mukherjee conceived the idea, prepared, collected data wrote, and revised the manuscript.

\section{REFERENCES}

1. Kidd C, Hayden BY. The psychology and neuroscience of curiosity Neuron 2015;88:449-60.

2. Buchanan RE. Life phases in a bacterial culture. J Infect Dis 1918;23:109-25. 